\title{
Sport Administration Evaluation in Turkey: Views of Sports Managers
}

Ali Türkmen ${ }^{1}$, Yeşer Eroğlu ${ }^{2}$

${ }^{1}$ York University, ali.turkmen@ outlook.com
${ }^{2}$ Gedik University, yeşer.eroglu@gedik.edu.tr

Received: 08.11.2017

Accepted: 05.12.2017

Online Published: 08.03.2018

doi: $10.30655 /$ besad.2018.4

\begin{abstract}
This study was carried out to evaluate the sport management in Turkey and to reveal its effect on success. For this purpose, interviews were held with six (4 male, 2 female) sportsmen in Turkey who have accomplished very important works in their fields. Interviews were held with the volunteers on the days and places of their choice. The survey method was chosen as the data collection tool in the research. In the analysis of the data, a descriptive analysis method was used, which allows the researcher to make a presentation by considering the questions or dimensions used in the interview and observation process. The data of the research made by the qualitative method were analyzed with NVIVO 10 program. The findings of the research, which were thought to be influenced by and influenced sport management, were collected under the themes of education, economy, political, social and international representation, differences between branches, and those worth-emphasizing. As a result of research, it was seen that a well arranged sport management was very important to primarily help managers to educate themselves and be up to date, to make sports politics in an applicable organisation, to keep the distance between politics and sports, and to make economic transfers among branches within a plan.
\end{abstract}

Keywords: Sport Management, Sports Manager

\section{Türkiye' de Spor Yönetimi Değerlendirmesi: Spor Yöneticisi Görüşleri}

\section{$\ddot{\mathbf{O} z}$}

Bu çalışma, gelişen spor sektörü üzerinde son derece önemli olan yöneticilerin, Türkiye' deki spor yönetimini değerlendirmesi ve başarıdaki etkisini ortaya çıkarmak amacıyla yapılmıştır. Bu amaçla Türkiye de kendi alanlarında son derece önemli işlere imza atmış 6 (4 Erkek, 2 Kadın) spor adamı ile görüşme yapılmıştır. Gönüllü katılımcılar ile kendi tercih ettikleri gün ve yerlerde görüşmeler gerçekleştirilmiştir. Araştırmada veri toplama aracı olarak "görüşme" yöntemi seçilmiştir. Verilerin analizinde araştırmacıya görüşme ve gözlem sürecinde kullandiğı soruları ya da boyutları dikkate alarak sunum yapma olanağı tanıyan betimsel analiz yöntemi kullanılmıştır. Nitel yöntemle yapılan araştırmanin verileri, NVIVO 10 programı ile çözümlenmiştir. Görüşmeler sonucu spor yönetiminin etkilediği ve etkilendiği düşünüldüğü araştırma bulgular eğitim, ekonomi, siyasal, toplumsal, uluslararası temsiliyet, branşlar arası farklılıklar ve özellikle vurgulanmak istenenler temaları altında toplanmıştır. Araştırma sonucunda; yöneticilerin öncelikle kendilerini yetiştirmelerinin ve yeni çağa uygun hala gelmelerinin önemi, spor politikalarının uygulanabilir bir düzende oluşturulması, spor ve siyaset arası mesafenin korunması ve branşlar arasında ekonomik aktarımın plan dahilinde yapılmasının düzenli bir spor yönetimini ile sağlanabileceği görülmüştür.

Anahtar Kelimeler: Spor Yönetimi, Spor Yöneticisi 


\section{Giriș}

Spor, ekonomik, sosyal ve kültürel kalkınmanın temel unsuru olan insanın beden ve ruh sağlığını geliştirmek, kişiliğin oluşumunu, karakter özelliklerinin gelişimini sağlamak, bilgi, beceri ve yetenek kazandırarak çevreye uyumu kolaylaştırmak, kişiler, toplumlar ve uluslar arası dayanışma, kaynaşma ve barışı sağlamak, kişinin mücadele gücünü arttırmak yanında belli kurallara göre rekabet ölçüleri içerisinde mücadele etme, heyecan duyma, yarışma ve yarışmada üstün gelme amacıyla yapılan faaliyetlerdir. Spor, bireyin tabii çevresini beşeri çevre haline getirirken elde ettiği yetenekleri geliştiren, belirli kurallar altında araçlı veya araçsız, bireysel ya da toplu olarak boş zaman faaliyeti kapsamı içinde veya profesyonelce meslekleştirerek yaptığı, sosyalleştirici, toplumla bütünleştirici, ruh ve fiziği geliştiren rekabetçi, dayanışmacı ve kültürel bir olgudur (Yetim, 2000).

İnsan topluluklarını millet yapan kültür unsurlarından biri de spordur. Spor kişisel olduğu kadar sosyal bir olaydır. Toplumların devamında, kültürlerinin korunması, kendilerini geliştirebilmeleri için başka yöntem, metot ve araçlar olduğu kadar spor ve sportif faaliyetler de etkili olmuştur. Toplumsal dayanışmanın sağlanmasında spor gibi bireyleri yakınlaştırıcı, birbirine kaynaştıran merkezlerin önemli rolleri vardır. Bilgi, davranış ve kabiliyetlerin geliştirilmesi ve kazandırılması için sürekli faaliyetler dizisi olan eğitim, sporu ve sportif faaliyetleri de içermektedir. Bir sosyal olay olarak spor, eğitim kapsamı içinde irdelenmelidir. Eğitim ve öğretim alt yapısını tamamlamış modern toplumların spordaki gelişmişliği, cinsiyet, eğitim ve spor ortamı ile direkt bağlantılıdır (Ramazanoğlu ve ark., 2005).

Her geçen gün, ilerleyen bilim ve teknolojinin yardımıyla spordaki rekorlar yenilendikçe, spor sahalarında adeta yarışan sporcu veya takımların temsil ettikleri ülkenin teknik, teknolojik, eğitim ve ekonomik standartları yarıştırır hale getirilmiştir. Sporun öneminin artmasının belli başlı sebepleri şu şekilde özetlenebilir (Doğu, 2011):

- $\quad$ Spor ile ilgili bilgilerin artması

- $\quad$ Spor ile ilgili programların gelişmesi

- $\quad$ Spor hizmeti sunulan nüfusun artması, örgütlerin çoğalması

- Yeni istihdam alanlarının ortaya çıkması

- $\quad$ Teknoloji kullanımının artması

- $\quad$ Sporun ülkeler arasında siyasi güç haline gelmesi

- Sporun uluslararası reklam aracı olarak kullanılmaya başlanılması,

- $\quad$ Sporun endüstrileşmesi 
- $\quad$ Sosyo-psikolojik faktörlerin önem kazanması

Yönetim çeşitli şekillerde tanımlanmıştır; ancak, bu çeşitli tanımların ortak öğeleri, ulaşılabilecek hedefler, sınırlı kaynaklar ile ve insanlar aracılığıyladır. . Yönetimsel çalışmanın amacı ve yöneticinin bir organizasyon içinde oynadı̆̆ı rolü, çalışanların yöneticinin istediği şeyleri verimli ve uygun maliyetli bir şekilde yapmasını sağlamaktır. Yönetim süreci, planlama, organizasyon, liderlik etme ve değerlendirme gibi bilgi alanlarını kullanarak gerçekleştirilir (Masteralexis ve ark., 2009)

Hammaddesi insan olan ve halkla sürekli ilişki içinde bulunan spor kurum ve kuruluşlarında dinamik bir yönetim yapısına sahip olması gerekir. Özellikle spor ortamını oluşturan yönetici, sporcu, eğitici, tesis, araç gereç ve sportif yarışma programları gibi unsurlar, amaçlara uygun olarak bir araya getirilmelidir.

Bu açıdan bakıldığında spor yönetimi; sporcu-yönetici, sporcu - spor teşkilatı ve spor teşkilatı ile halk arasındaki ilişkileri düzenleyen bir mekanizma olarak da değerlendirilebilir. Öte yandan, spor kulüpleri, milli ve uluslararası spor kuruluşları ile uluslararası spor organizasyonları, spor yönetiminin ne kadar geniş boyutlar ihtiva ettiğini göstermektedir (Sunay, 1998).

Spor yönetimi alanı eski çağlardan beri gelişimini sürdürmektedir. Akademik olarak her ne kadar yeni bir kavram olarak ele alınsa da, literatürde akla yatkın çalışma alanı olarak uzun zamandır kabul görmektedir (Ekmekçi, 2016).

Genel yönetimin bir parçası olan spor yönetimini, genel yönetimden ayırmak mümkün değildir. Bir başka ifade ile genel yönetimde kullanılan kavram ve yöntemler spor yönetimi içinde aynen geçerlidir. Bu noktadan hareketle spor yönetimi, genel yönetimin ilke, yönetim ve kurallarının spor alanına uygulanışı olarak da kabul edilebilir. Temel amacı da, spor faaliyetlerinin akılcı ve bilimsel bir biçimde yürütülmesinin yollarını araştırmak, bulmak ve bunları genel ilkelere dönüştürüp uygulamaktır. Başka bir ifade ile spor yönetimi, spor alanına ilişkin karar ve hedeflerin gerçekleştirilmesine yönelik faaliyetlerle ilgilenir (Vural, 2013).

Bu doğrultuda üstünde bu kadar durulan Türkiye de ve uluslararası platforma son zamanların revaçta meslek grubu olarak görülen spor yönetiminin günümüzdeki durumunun alanında son derece önemli spor yöneticilerinden görüş alınarak değerlendirilmesi amaçlanmıştır. 


\section{Yöntem}

\section{Araştırma Modeli}

$\mathrm{Bu}$ araştırma nitel araştırma yaklaşımına dayalı bir fenomenolojik araştırmadır. Fenomenoloji felsefi ve psikolojik bakıları temel alan bir araştırma desenidir. Bu araştırma yaklaşımı, insan olgusu üzerine odaklanan, yaşanmış deneyimlerin ifade edilişinin anlamlarını tanımlamayı amaçlayan tümevarımsal betimleyici bir araştırmadır (Şaban ve Ersoy, 2016).

\section{Katılımcilar}

Bu araştırma alanında uzman 6 (4: Erkek, 2: Kadın) spor yöneticisi ile yapılmıştır. Katılımcıların belirlenmesinde nitel araştırmanın doğasına uygun şekilde amaçlı örneklem yöntemlerinden kolay ulaşılabilir durum örneklemesi kullanılmıştır. Bu örnekleme yöntemi araştırmacıya hız ve pratiklik kazandıran bir yaklaşımdır. Bu amaçla araştırmacı bu çalışmayı görüşmeyi gönüllü kabul eden spor yöneticileri ile yürütmüştür. Yöneticiler Y (Y1, Y2.....) harfi ile simgelenmiştir.

Tablo 1: Katılımc1 Profili

\begin{tabular}{|c|c|c|c|}
\hline Katılımcı & Ĕgitim & Görev & Sportif Geçmiş \\
\hline Yönetici $1(\mathrm{Y} 1)$ & Doktora & $\begin{array}{l}\text { Spor Bilimler Fakültesi } \\
\text { Dekanı }\end{array}$ & $\begin{array}{l}12 \text { yıl aktif sporculuk, } 10 \text { yıl Milli Takım Antrenörlüğü, } \\
7 \text { yıl federasyon as başkanllğ̆ı, } 14 \text { yıl spor yüksekokulu } \\
\text { müdürlüğü, } 5 \text { yıl spor fakültesi dekanlığı. }\end{array}$ \\
\hline Yönetici $2(Y 2)$ & Yüksek Lisans & İlçe Müdürü & $\begin{array}{l}10 \text { y1l aktif sporcu, } 6 \text { y1l Spor servisi, } 4 \text { y1l Şube } \\
\text { Müdürlüğü, } 1 \text { y1l İlçe Müdürlüğü }\end{array}$ \\
\hline Yönetici 3 (Y3) & Lisans & $\begin{array}{l}\text { FIBA Yönetim Kurulu } \\
\text { Üyesi - Kulüp Başkanı }\end{array}$ & $\begin{array}{l}20 \text { yıl aktif sporcu, } 15 \text { yıl milli takım oyuncusu, Milli } \\
\text { takım menajerliği, Federasyon başkanlığı. }\end{array}$ \\
\hline Yönetici 4 (Y4) & Lisans & Direktör & $\begin{array}{l}20 \text { yıl aktif sporcu, } 5 \text { y1l milli takım oyuncusu, } 10 \text { yıl } \\
\text { spor yöneticiliği }\end{array}$ \\
\hline Yönetici 5 (Y5) & Lisans & $\begin{array}{l}\text { Takım menejerliği, } \\
\text { Belediye Başkan } \\
\text { Danışmanlığı }\end{array}$ & 15 y1l sporcu, Antrenör, 15 y1l yönetim kademesi \\
\hline Yönetici 6 (Y6) & Lisans & Yönetim Kurulu Üyesi & 6 y1l Spor Yöneticiliği \\
\hline
\end{tabular}

\section{Verilerin Toplanması}

Araştırmada " yarı yapılandırılmış görüşme” tekniği kullanılmıştır. Bu görüşme hazırlanmış bir dizi sorudan oluşur ve her görüşülen bireye bu sorular aynı tarzda ve sırada sorulur. $\mathrm{Bu}$ anlamda bu yaklaşım, bir araştırmada birden fazla görüşmecinin becerileri, yanlılıkları veya öznelliklerinden kaynaklanabilecek farklılıkları da azaltmış olur (Yıldırım ve Şimşek, 2013).

\section{Verilerin Analizi}

Araştırmada betimsel analiz ve içerik analizi kullanılmıştır. Betimsel analizde, ses kaydı kullanılarak elde edilen veriler nitel araştırmada uzman olan araştırmacı tarafından işlenmiş ve elektronik ortama aktarılmıştır. Ayrıca, araştırmacı tarafından tutulan kısa notlar ile 
bulguların tutarlı olup olmadıkları karşılaştırılmıştır. Verilerin içerik analizinde öncelikle yüz yüze görüşme ile elde edilen veriler bilgisayar ortamında düz yazı haline getirilmiş daha sonra bu veriler NVIVO 10 programına aktarılmıştır. NVIVO verilerin ve kaynakların sistematik bir şekilde sınıflandırılması, kodlanması, temalara ulaşılması ve ulaşılan sonuçların bir model olarak ortaya konması ile ilgili araştırmacılara kolaylık sağlamaktadır.

Verilerin analizi sürecinde yapılan tüm işlemler araştırmacı ve nitel araştırma konusunda deneyimli üç uzman tarafından birbirinden bağımsız olarak gerçekleştirilmiştir. Yapılan kodlamalarda birbiri ile örtüşen ifadeler tema olarak gruplandırılmıştır.

\section{Geçerlik ve Güvenirlik}

Lincoln ve Guba (1985) nitel araştırmalarda geçerlik ve güvenirliği sağlamak amacıyla inandırıcılık, aktarılabilirlik, tutarlık ve teyit edilebilirlik kavramlarını kullanılmasını önermektedirler (akt: Yıldırım ve Şimşek, 2013).

Inandırıcılık; uzun süreli etkileşim, çeşitleme ve derinlik odaklı veri toplama, uzman incelemesi ve katılımcı teyidi gibi yöntemlerle sağlanabilmektedir. $\mathrm{Bu}$ çalışmadaki araştırmacıların 20 yılı aşkın süredir spor camiasının içinde yer alması (sporcu-antrenöryönetici) alan ile uzun süreli etkileşimi güçlendirerek veri kaynakları üzerindeki öznel algılardan kaynaklanan durumları anlamasında etkili olmuştur. Bununla birlikte yüz yüze görüşmeler ile birlikte araştırmacının üstlenmiş olduğu katılımcı gözlemci rolü gereği görüşme süresince tuttuğu notları, verilerin elde edilmesinde veri çeşitliliği sağlayarak (Tobin ve Begley, 2004) çalışmanın inandırıcılığını artırmaktadır.

Nitel araştırmada genelleme yerine benimsenen aktarılabilirlik özelliğinin güçlendirilebilmesi (Yıldırım ve Şimşek, 2013) amacıyla, araştırmada amaçlı örnekleme yöntemlerinden kolay ulaşılabilir durum örneklemesi kullanılmıştır.

Araştırmanın tutarlılığı için veriler araştırmacı ile birlikte iki alan uzmanı tarafından yapılmış ve temalar oluşturulmuştur. Araştırmacı ve alan uzmanlarının belirlediği kod ve temalar için "görüş birliği” ve “ görüş ayrılığı” olan ifadeler belirlenmiştir. Araştırmanın güvenirlik hesaplaması için Miles ve Huberman'ın (1994) güvenirlik formülü kullanılmıştır.

Uzlaşma Yüzdesi \% = $[\mathrm{Na}$ (Görüş Birliğii) $/ \mathrm{Na}$ (Görüş Birliği) $+\mathrm{Nd}($ Görüş Ayrılı̆̆ 1$)]$ X 100

Toplam ifadeler için görüş birliği 64, görüş ayrılığı 14 kod olarak belirlenmiştir. Miles ve Huberman'ın (1994) formülüne göre araştırmanın güvenirliği \%82 olarak hesaplanmıştır. 
Güvenirlik sonuçlarının \%70'in üzerinde çıkması araştırmanın güvenirliği açısından geçerli bir orandir (Miles ve Huberman; 1994).

Araştırmanın teyit edilebilirliği (dış güvenirlik) için, araştırmada kullanılan tüm veri toplama araçları, ham veriler, analiz aşamasında yapılan kodlamalar, gerektiği zaman tekrar incelenebilmek üzere araştırmacı tarafından saklı tutulmaktadır.

\section{Bulgular}

Katılımcılar gelişen ekonomik ve endüstri dünyasında sporun kitlelere ulaşmada son derece önemli bir araç olduğunu, doğru ellerde yönetildiğinde ülke tanınırlığını arttırma anlamında faydası olacağını ifade etmişlerdir. Alan içinden gelsin ve ya gelmesin spor eğitimi almış kişilerin sporun gelişimine katkısının kaçınılmaz olduğu da vurgulanmıştır. Sporu yöneten insanların kendi gelişimlerini de devam ettirerek yeni yüzyılın hedeflerine uygun hale gelmesi önemi detay sonuçlar arasındadır. Sporun kurumsal bir kimliğe ulaşmasının üzerindeki etkilerin arttırılmasının olumlu katkıları vurgulanmıştır. Genel sonuçlar araştırmacı tarafından hazırlanan aşağıdaki şemada özetlenmiştir.

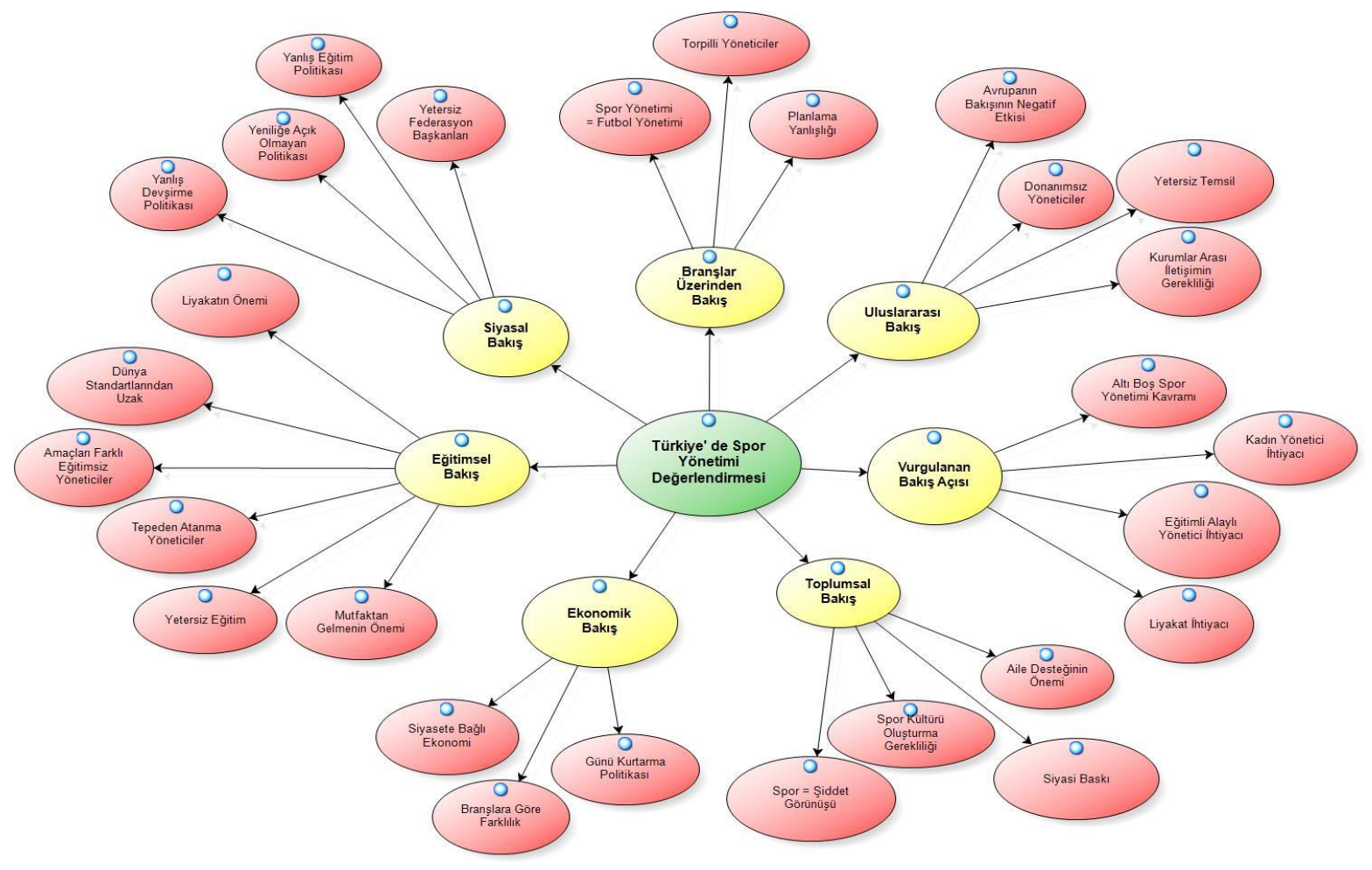

Eğitimsel Bakış; yetersiz eğitim, dünya standartlarından uzak, amaçları farklı eğitimsiz yöneticiler, liyakatın önemi, tepeden atanma yöneticiler ve mutfaktan gelmenin önemi; Ekonomik Bakış; branşlara göre farklılık, günü kurtarma politikası ve siyasete bağlı ekonomi; Siyasal Bakış yetersiz federasyon başkanları, yanlış devşirme politikası, yanlış 
eğitim politikası ve yeniliğe açık olmayan politikalar; Toplumsal Bakış; siyasi baskı, spor = şiddet görünüşü, spor kültürü oluşturma gerekliliği ve aile desteğinin önemi; Uluslar Arası Bakış; Avrupa'nın bakışının negatif etkisi, yetersiz temsil, donanımsız yöneticiler ve kurumlar arası iletişimin gerekliliği; Branşlar Üzerinden Bakış; planlama yanlışlığı, torpilli yöneticiler ve spor yönetimi = futbol yönetimi; Vurgulanan Bakış Açısı; liyakat ihtiyacı, kadın yönetici ihtiyacı, altı boş spor yönetimi kavramı ve eğitimli alaylı yönetici ihtiyacı temaları-kodları ile sunulmuştur (Şema 1).

Tema ve kodları ortaya çıkartan yönetici görüşleri Tablo 2-3-4-5-6-7-8' de verilmiştir.

Tablo 2: Tema ve Kodlar Tablosu (Eğitimsel Bakış)

\begin{tabular}{|c|c|c|}
\hline TEMALAR & KODLAR & YÖNETÍCI \\
\hline \multirow{6}{*}{$\begin{array}{l}\text { Ĕ̈́ITIMMSEL } \\
\text { BAKIŞ }\end{array}$} & YETERSİZ EĞİTİM & $\begin{array}{l}\text { Beden Eğitimi ve Spor Yüksek Okullarında spor yöneticiliği bölümleri var fakat } \\
\text { yeterince istihdam sağlanmıyor. Bu alanda eğitim almış insan sayısı çok değil (Y5) }\end{array}$ \\
\hline & $\begin{array}{l}\text { DÜNYA } \\
\text { STANDARTLARINDAN } \\
\text { UZAK }\end{array}$ & $\begin{array}{l}\text { Türkiye genelde eğitim alınıyor ama bu insanlar üzerinde değişiklik yapsın diye değil } \\
\text { sadece bir titre olsun diye. Ben de şu üniversiteye girdim diyebilmek için. Hatta } \\
\text { ellerinden gelse üniversite diplomasına para verip almaya çalışacaklar. Türkiye'de } \\
\text { eğitime ne yazık ki bu gözle bakılıyor. Dünya standartlarını yakalamamız için } \\
\text { eğitime çok ihtiyacımız var (Y3) }\end{array}$ \\
\hline & $\begin{array}{l}\text { AMAÇLARI FARKLI } \\
\text { EĞİTİMSİZ YÖNETİCİLER }\end{array}$ & $\begin{array}{l}\text { Genel olarak spor eğitimi almamış farklı vizyon, reklam amaçlı kurumsal } \\
\text { düzeylerine katkı sağlamak isteyen, konum (maddi-sosyal) avantajı olan kişilerin } \\
\text { spor yönetiminde olduğunu düşünüyorum (Y6) }\end{array}$ \\
\hline & LIYAKATIN ÖNEMİ & $\begin{array}{l}\text { Spor alanında ne eğitimi, ne tecrübesi, ne de sporcu geçmişi olmayan kişiler atanmış } \\
\text { olup sporu geriye çekmektedir. Umarım sporun önemini kavrayan, bu alanda projeler } \\
\text { geliştirip uygulayan yöneticilerimizin sayısı artar (Y2) }\end{array}$ \\
\hline & $\begin{array}{l}\text { TEPEDEN ATANMA } \\
\text { YÖNETÍCIILER }\end{array}$ & $\begin{array}{l}\text { Bizde daha çok tepeden gelme eğitimin çok önemli olmadığı, dönemin hükümetine } \\
\text { yakın kişiler işin içine katılıyor. Bu da tabii ki yönetim sistemimizi bozuyor (Y1) }\end{array}$ \\
\hline & $\begin{array}{l}\text { MUTFAKTAN GELMENIN } \\
\text { ÖNEMİ }\end{array}$ & $\begin{array}{l}\text { Bence her ikisi de gereklidir. Örnek verecek olursak; kriz anlarında doğru karar } \\
\text { vermeyi spordaki oyunculuk ve/veya yöneticilik tecrübem sayesinde başarırken, } \\
\text { organizasyon planlamalarımda ve yanımda çalışanlar ile iletişimimde aldı̆̆ım } \\
\text { yönetim eğitimimden yararlanmaktayım(Y4) }\end{array}$ \\
\hline
\end{tabular}

Tablo 3: Tema ve Kodlar Tablosu (Ekonomik Bakış)

\begin{tabular}{|c|c|c|}
\hline TEMALAR & KODLAR & YÖNETİCI \\
\hline \multirow{3}{*}{$\begin{array}{l}\text { EKONOMIK } \\
\text { BAKIŞ }\end{array}$} & $\begin{array}{l}\text { BRANŞLARA GÖRE } \\
\text { FARKLILIK }\end{array}$ & $\begin{array}{l}\text { Voleybol üzerinden değerlendirmek isterim. Dünya da ülkemizi temsil eden bu spor } \\
\text { dalının futbol sporunun desteklenmesinin yarısı kadar desteklenmediğini } \\
\text { düşünüyorum (Y6) }\end{array}$ \\
\hline & $\begin{array}{l}\text { GÜNÜ KURTARMA } \\
\text { POLITİKASI }\end{array}$ & $\begin{array}{l}\text { Bence kulüpler maddiyat açısından son derece büyük yatırımlar alıyor. Kulüp } \\
\text { yöneticileri bu yatırımları doğru değerlendiremediler. Günü kurtarmaya çalıştılar. } \\
\text { Bugünü kurtarayım hesabına gidildi(Y3) }\end{array}$ \\
\hline & $\begin{array}{l}\text { SIYYASETE BAĞLI } \\
\text { EKONOMİ }\end{array}$ & $\begin{array}{l}\text { Baştakiler istedikleri zaman ekonomik boyut açısından her zaman düzgün dağıtım } \\
\text { sergilerler. Kaynaklar bulurlar. Hatta gereğinden fazla bile destek sağlarlar (Y1) }\end{array}$ \\
\hline
\end{tabular}

Tablo 4: Tema ve Kodlar Tablosu (Siyasal Bakış)

\begin{tabular}{|c|c|c|}
\hline TEMALAR & KODLAR & YÖNETÍCI \\
\hline \multirow{4}{*}{$\begin{array}{l}\text { SIYYASAL } \\
\text { BAKIŞ }\end{array}$} & $\begin{array}{c}\text { YETERSİZ FEDERASYON } \\
\text { BAŞKANLARI }\end{array}$ & $\begin{array}{l}\text { Yönetim üzerinde son derece fazla etkili. Bir federasyonun başkanı istedikleri gibi } \\
\text { seçtirebilirler. Örneklerine bakarsak o zaman siyasal boyutun ne kadar etkili } \\
\text { olduğunu görebiliriz (Y1) }\end{array}$ \\
\hline & $\begin{array}{l}\text { YANLIŞ DEVŞİIRME } \\
\text { POLITIKIKASI }\end{array}$ & $\begin{array}{l}\text { Devşirme sporcuların ülkemiz adına yarışıp başardık demeyi çok doğru bulmuyorum. } \\
\text { Ülkemizde bu kadar genç nüfus varken biz daha iyisini yapabiliriz (Y5) }\end{array}$ \\
\hline & $\begin{array}{l}\text { YANLIŞ EĞİTiM } \\
\text { POLITIIKASI }\end{array}$ & $\begin{array}{l}\text { Türkiye' de eğitim sistemi spora izin vermiyor. Çocuklarımıza spor yapacak vakti } \\
\text { kalmıyor. }\end{array}$ \\
\hline & $\begin{array}{c}\text { YENİİĞG AÇIK } \\
\text { OLMAYAN POLİTİKA }\end{array}$ & Gelişmeyen, dönüşmeyen klasik politikalar ile spor yönetilmeye devam ediyor (Y6) \\
\hline
\end{tabular}


Tablo 5: Tema ve Kodlar Tablosu (Toplumsal Bakış)

\begin{tabular}{|c|c|c|}
\hline TEMALAR & KODLAR & YÖNETİCI \\
\hline \multirow{5}{*}{$\begin{array}{l}\text { TOPLUMSAL } \\
\text { BAKIŞ }\end{array}$} & SIYASİ BASKI & $\begin{array}{l}\text { Türkiye'de sporun yöneten yöneticilerdir toplum değil. Bizim belediye başkanımızın } \\
\text { spora karşı ilgisi var. Dolayısıyla kulüplere destek verip kulüplerle toplantı yapıp, } \\
\text { kararlar üstünde yetki sahibi oluyor. Bu üst kademede de aynı (Y1) }\end{array}$ \\
\hline & $\begin{array}{l}\text { SPOR = ŞİDDET } \\
\text { GÖRÜNÜŞÜ }\end{array}$ & $\begin{array}{l}\text { Maalesef bir takım branşlarda özellikle futbolda bir kavga gürültü var. Bu yıllardır } \\
\text { şehirleri ikiye bölecek kadar, otobüslere ateş açacak kadar, maçlarda birbirlerini } \\
\text { bıçaklayıp öldürecek kadar gelmiş toplumumuzda. Bunları bu duruma getiren de } \\
\text { yöneticiler (Y3) }\end{array}$ \\
\hline & SPOR KÜLTÜRÜ & En büyük sorunumuz; okuldan kalmasın, mayo giymesin, her gün gitmesin derken \\
\hline & GEREKLİLİĞİ & $\begin{array}{l}\text { ki ama yeterli değil. Toplumun bakışının değişmesi için okullarda müdür ve } \\
\text { ögretmenlerin sporu bilinçlendirme, akabinde de yönlendirme yapmaları etkili } \\
\text { olabilir (Y2) }\end{array}$ \\
\hline & $\begin{array}{l}\text { AİLE DESTEĞİNIN } \\
\text { ÖNEMİ }\end{array}$ & $\begin{array}{l}\text { Eskiden bizim zamanımızda gizli futbol oynardık şimdi aileler kendileri çocuklarını } \\
\text { spor yapmalarına teşvik ediyor. Spor kültürümüzün gelişmesi için küçük yaşlardan } \\
\text { itibaren çocuklarımıza sporu sevdirmeliyiz (Y1) }\end{array}$ \\
\hline
\end{tabular}

Tablo 6: Tema ve Kodlar Tablosu (Uluslararası Bakış)

\begin{tabular}{|c|c|c|}
\hline TEMALAR & KODLAR & YÖNETİCI \\
\hline \multirow{5}{*}{$\begin{array}{l}\text { ULUSLARARASI } \\
\text { BAKIŞ }\end{array}$} & $\begin{array}{l}\text { AVRUPANIN BAKIŞININ } \\
\text { NEGATİF ETKISII }\end{array}$ & $\begin{array}{l}\text { Uluslararası bir kurumda da şu anda yöneticilik yaptığım için oralarda çok daha az } \\
\text { kavga ile sorunlar çözülüyor ve spor için ortak kararlar alınıyor. Fakat dışarıdan } \\
\text { Türkiye ye bakıldığı zaman daha agresif yöneticiler. Hatta agresif olmaz ise kendisini } \\
\text { zayıf hisseden yöneticiler mevcut (Y3) }\end{array}$ \\
\hline & YETERSİZ TEMSİL & $\begin{array}{l}\text { Yurt dışındaki temsiliyetimizin sporcu, antrenör ve yönetici bazında yetersiz } \\
\text { olduğunu düşünüyorum. ne yazık ki örneklerde ortada. Bir elin parmakları kadar(Y6) }\end{array}$ \\
\hline & DONANIMSIZ & Öncelikle dilleri yok. Yönetimde olan insanların en azından bir nebze dillerin olması \\
\hline & YÖNETİCİLER & gerekir. Bundan rahatsız olup kendini geliştiren yöneticiler de yok ne yazık ki. \\
\hline & $\begin{array}{l}\text { KURUMLAR ARASI } \\
\text { İLTIŞ̧IMIN } \\
\text { GEREKLİLIĞİ }\end{array}$ & $\begin{array}{l}\text { Spor kültürümüzün daha gelişmesi için ilkokuldan itibaren çocuklarımıza sporu } \\
\text { sevdirmeli ve kesinlikle Milli Eğitim Bakanlığı ile birlikte daha ciddi politikalar } \\
\text { üretilmeli (Y5) }\end{array}$ \\
\hline
\end{tabular}

Tablo 7: Tema ve Kodlar Tablosu (Branşlar Üzerinden Bakış)

\begin{tabular}{|c|c|c|}
\hline TEMALAR & KODLAR & YÖNETICI \\
\hline \multirow{6}{*}{$\begin{array}{l}\text { BRANŞLAR } \\
\text { ÜZERINDEN } \\
\text { BAKIŞ }\end{array}$} & PLANLAMA YANLIŞLIĞI & Bunu objektif değerlendirebilmemiz için bence en önemli kıstas bütçedir. Spor \\
\hline & & 52 federasyona aktarımlar plansızdır. Aktarılan bazı rakamlar ile federasyonun \\
\hline & & yönetilmesi imkansızdır (Y4) \\
\hline & TORPILLI YÖNETICILIER & Sporun biraz siyasetten kurtulması gerekir. Bu kadar siyaset işin için de olmamalı. \\
\hline & & $\begin{array}{l}\text { Delege sistemi düzgün oturtulmalı geniş tutulmalı o sporun içinden gelen insanlar } \\
\text { tercih edilmeli. Siyaset işin içine girince sadece siyasete yakın oldukları için } \\
\text { federasyon koltuklarına oturuyorlar. Oturunca da tabi ki adamın da spor ile çok fazla } \\
\text { donanımı yok ise o spor branşı ileriye gidemiyor (Y3) }\end{array}$ \\
\hline & $\begin{array}{l}\text { SPOR YÖNETIMİ = } \\
\text { FUTBOL YÖNETIMİ }\end{array}$ & $\begin{array}{l}\text { En popüler olan branş tüm dünyada olduğu gibi ülkemizde de futbol. Son yıllarda } \\
\text { kulüplerin özellikle yayin gelirlerinin artmas1 futbol ekonomisini daha da büyüttü. }\end{array}$ \\
\hline
\end{tabular}

Tablo 8: Tema ve Kodlar Tablosu (Vurgulanan Bakış Açısı)

\begin{tabular}{|c|c|c|}
\hline TEMALAR & KODLAR & YÖNETİCI \\
\hline & LIYAKAT İHTIYACI & Yönetici atamalarında liyakat esas olarak alınmalıdır (Y2) \\
\hline \multirow[t]{3}{*}{$\begin{array}{l}\text { VURGULANAN } \\
\text { BAKIŞ AÇISI }\end{array}$} & $\begin{array}{l}\text { KADIN YÖNETİCİ } \\
\text { İHTIYYACI }\end{array}$ & $\begin{array}{l}\text { Voleybol spor kulübü yöneticisi olarak özellikle kadınların olduğu branşlarda bile } \\
\text { erkek yönetici görüyorum. Bu durumu çok yanlış buluyorum. Her dalda kadın } \\
\text { yönetici olması gerektiği gibi kadın sporcuların olduğu sporlarda mutlaka ve mutlaka } \\
\text { kadın yöneticiler olmalı (Y6) }\end{array}$ \\
\hline & $\begin{array}{l}\text { ALTI BOŞ SPOR } \\
\text { YÖNETIMII KAVRAMI }\end{array}$ & $\begin{array}{l}\text { Ben Türkiye de spor yönetimi var } \mathrm{m} ı \text { acaba diye sormak isterdim. Kocaman bir soru } \\
\text { ișareti benim icin (Y1) }\end{array}$ \\
\hline & $\begin{array}{l}\text { EĞİTIMLİ ALAYLI } \\
\text { YÖNETICI İHTIYACI }\end{array}$ & $\begin{array}{l}\text { Gittikçe büyüyen spor ekonomisini hem iyi eğitim almış, yabancı dil bilen hem de } \\
\text { sporcu geçmişi olan alaylı dediğimiz kişilerin tecrübesini buluşturup bu alanı } \\
\text { profesyonel kişilere bırakılmasını diliyorum (Y5) }\end{array}$ \\
\hline
\end{tabular}




\section{Tartışma ve Sonuç}

Araştırmada yöneticilerin öncelikle kendilerini yetiştirmelerinin ve yeni çağa uygun hala gelmelerinin önemi, spor politikalarının uygulanabilir bir düzende oluşturulması, spor ve siyaset arası mesafenin korunması ve branşlar arasında ekonomik aktarımın plan dahilinde yapılmasının düzenli bir spor yönetimini ile sağlanabileceği görülmüştür. Sporun kendisi ile ortak paydaşları arasında olumlu işbirliği ile uluslararası boyutta daha iyi temsil edilebileceği ifade edilebilir.

Çalışmamızın sonucunda spor yönetimi eğitimi olmasa da her hangi bir lisans eğitimi almış olmanın spor yönetim alanına pozitif bir etki yaratacağı vurgulanmıştır. Bu bağlamda; çalışmamızı destekler nitelikteki sonuçlar diğer araştırmalarda da göze çarpmaktadır. Örneğin, Özen ve arkadaşlarının (2012) yapmış oldukları çalışmada sağlıklı bir spor ortamının oluşturulması yönetim ve organizasyonların yanında bu sistemi yönlendirecek ve geliştirecek bilgi birikimine sahip uzman kişilerin olmasını gerektirmekte olduğu vurgulanmıştır. Spor alanında insan kaynağı olarak nitelendirilen; sporcu, antrenör, monitör, yönetici, mühendis, eğitimci, doktor, işletmeci, vb. uzmanların tamamen spor alanındaki kurum ve organizasyonlara yönelik eğitilip istihdam edilmesi, sporda kalite ve verimliliği artırarak, sporun gelişmişlik ve yaygınlık düzeyine olumlu etkisi ile birlikte sportif başarılara da önemli ölçüde yansıyacağının bir gerçek olduğu ifade edilmiştir. Katılımcıların yarısından fazlası spor yöneticilerinin çağdaş yönetim ilke ve fonksiyonlarını kendi spor organizasyonlarında uygulayacak vizyona sahip olmadıklarını, aynı zamanda spor yöneticilerinin yeterli düzeyde yabancı dil bilgisine sahip olmadıklarını düşünmektedirler. Benzer şekilde, spor kulüplerinin alanında eğitimli spor elemanlarını yeterince istihdam etmediğini de düşünmektedirler. Anlaşılacağı üzere tüm bu bulgular, spor yöneticilerinin kendi alanlarında yeterli donanıma sahip olmadıkları sonucuna ulaşmışlardır. Uyar ve Sunay'ın (2009) da yapmış oldukları çalışmada eğitim boyutunun önemi, spor kulüplerinde üniversite mezunu spor yöneticisinin bulunması federasyonun etkinliğini artırır sorusuna verilen cevaplarda olumlu katılım oranının en yüksek düzeyde olduğu sonucu ile ortaya çıkmıştır. Buna göre federasyonlarda daha çok spor yöneticisi çalıştırılması federasyonun işlerini daha kısa sürede etkin ve verimli bir şekilde yapmasını sağlayacaktır. Bu nedenle federasyonlarda daha fazla spor yöneticisinin çalışabilmesi için gerekli düzenlemeler yapılmalıdır sonucuna ulaşılmıştır. $\mathrm{Bu}$ sonuçlar çalışmamız ile paralellik gösterirken; Gökçe ve arkadaşlarının (2008) de yapmış oldukları çalışma sonucunda fahri spor yöneticileri, toplumun her kesiminden ve meslek gruplarından olabileceği ifade edilmiştir. Karşılıksız olarak sporun gelişmesi ve yaygınlaştırılması için 
toplumsal bir görev üstlenen kulüp yöneticileri insanlar ile ilişkilerindeki sağlıklı iletişim sonunda toplum içerisinde farklı, saygın bir yer edinmekte olduğunu ifade ederek aksi bir savı ifade etmiştir. Zeigler (2007) de yapmış olduğu çalışmada günümüz dünyasının spor ortamına hizmet edebilen bilimsel bulgulara dayanan modern disiplin ve teorilere ihtiyaç duyulduğunu vurgulamıştır. Skinner ve Gilbert (2007) de yapmış oldukları çalışmaları sonucunda kaliteli spor yönetimi eğitiminin nasıl verileceğinin tam olarak çözülmemesine rağmen spor yönetimi eğitiminin alandaki kişiler için zorunlu hale getirilmesinin önemini vurgulamıştır.

Ekonomik yatırımların son derece yeterli olduğu devlet ve özel sektörler tarafından desteklendiği vurgulanmış, fakat bu yatırımların yanlış planlama ve yanlış ellerden yürütülmesinden kaynaklanan sıkıntılar yaşandığı sonucuna ulaşılmıştır. Ekonomik boyutta bakıldığında araştırmayı destekler nitelikteki diğer çalışma sonuçları; Şahin ve İmamoğlu'nun (2011) araştırmalarında görüşü alınan milletvekillerinin "devletin spor faaliyetlerine ayırdığ bütçeyi Türkiye'nin şartlarına göre yeterli” bulmadığı, Güngörmüş ve arkadaşlarının (2007) araştırmasında, milletvekillerinin genel bütçe içerisinden spora ayrılan bütçe "yeterli değildir" şeklinde görüş bildirmiş ve bu sonuçlar çalışmamız ile doğru orantılı olarak vurgulanmıştır.

Çalışma sonuçları siyasetin spor üstü olduğu ve sporun üstündeki siyaset baskısının azaltılması gerekliliği vurgulanmıştır. Spor politikalarının yeni çağa uygun hale getirilmesi önemle vurgulanmıştır. Aynı doğrultuda; Şahin ve İmamoğlu'nun (2011) akademisyen ve milletvekili görüşü alarak yapmış olduğu çalışmada siyasetin rolü ile ilgili görüşleri ile ilgili yorumu çoğunluk olarak siyasetin rolünün olduğu fakat olmaması gerektiği, hükümet politikalarının öncelikli olarak fiziki altyapı yatırımlarına destek vermesi gerektiği, "bir spor politikası ya da programı oluşturmadaki en büyük engelin” spor bilinci yoksunluğu olduğunu vurguladıkları tespit edilmiştir. İnce'nin (2016) yapmış olduğu çalışma sonuçlarında da siyasilerin spor olgusunun nimetlerinden yararlanmak adına ulusal ve uluslararası düzeyde başarılar elde etmiş isimleri milletvekili adayı yaparak ulusal manada destek bulmayı amaçlamaları, katıldıkları her mitingde o bölgenin ya da kentin takımlarına ait kaşkol ya da formalarla meydanlarda konuşmayı uygun görmeleri, destekçilerini artırmak adına sporun nimetlerinden faydalanmayı düşünmeleri ifadeleri başka bir bakış açısı kazandırmıştır. Victor (2009) da siyaset ve spor adlı çalışmasında siyasi rekabetin sporun üstüne çıktığı ve hükümetlerin spor ile siyasi savaşlarını sürdürdügünü ve bunun spor organizasyonlarının eğlencesine gölge düşürdüğünü vurgulamıştır. Costa (2005) dünyanın dört bir yanından 17 spor yönetimi uzmanı ile yapmış olduğu çalışmada, spor yönetimi araştırmaları, uygulamaları, teorisi ve eğitimi ile ilgili tartışmaların devam etmesinin o alanın büyümekte olduğunun 
göstergesi olarak ifade etmiştir. Spor yönetim uzmanları ayrıca yeterli ve yapıcı gelişimi sağlayabilmek için modern spor politikalarının gerekliliğini vurgulamıştır.

Uluslararası boyutlarda bakıldığında Avrupa' ya oranla spor yönetimi programları, politikalar ve düzenlemeler konusunda henüz daha gerilerde olduğumuz ifade edilmiştir. Sporun ülkelerin tanınılırlığına katkısının göz ardı edilemeyeceği ise üzerinde bastırılarak durulan bir sonuç olarak karşımıza çıkmaktadır. Destekler nitelikteki çalışmalara bakıldığında; Şahin ve İmamoğlu'nun (2011) yapmış oldukları çalışmada uluslararası boyut açısından bakıldığında "uluslararası müsabakaların ülkeler açısından anlamının” itibar olduğunu ve uluslararası spor müsabakalarının ülkelerin dünya kamuoyundaki itibarına katkı yaptığını ifade etmişlerdir. Uyar ve Sunay'ın (2009) yapmış oldukları çalışmada Uluslararası temsil boyutunda, üniversite spor yöneticiliği mezunlarının Türk sporuna ve topluma katkıları hakkında sorular sorulmuş, katılımcıların tamamı üniversite spor yöneticiliği mezunlarının Türk sporuna ve topluma katkılarının yüksek düzeyde olduğu şeklinde görüş belirtmişlerdir.

Toplumsal boyut anlamında bakıldığında; toplumun sporu tanımlamasında hatalar olduğu, paydaş örgütler arasında iletişim sorunlarından kaynaklı olarak (Spor Fakülteleri, Milli Eğitim, Bakanlık, Federasyonlar) sporun gelişiminin yavaş ilerlediği ortaya konulmuştur. Sporun toplumlar üzerindeki öneminin ortaya koyan çalışmalara bakıldığında; Yazıcı' nın (2014) yapmış olduğu çalışmada spor artık günümüzde yan faaliyet alanları ve yardımcı kuruluşları ile tam bir sektör hüviyetini kazanmıştır. Milyonlarca insan bu sektörden ekmeğini kazanmaktadır. Spor; ülkelerin kalkınmışlığının en önemli kriterlerinden birisi kabul edilmekte, hatta geri kalmış ve gelişmekte olan ülkelerin ilerleyebilmeleri, gelişmiş ülkeler ile entegrasyona girebilmelerinin yegâne yolu olduğu iddia edilmektedir. Sağlıklı bir toplum olmakta, dünya ile bütünleşmekte, kalkınmakta, sosyal adaletli, temiz çevreli bir toplum olmakta sporun yeri ve önemi inkâr edilecek gibi olmadığını vurgulamıştır. Aykın'ın (2013) yapmış olduğu çalışmada birçok ülkenin spor politikasında olduğu gibi, ülkemizin spor politikasında da sporun topluma yaygınlaştırılması ilk sırada yer almaktadır. Parti ve Hükümet Programları ile Kalkınma Planları incelendiğinde de, bu durum açıkça görülmektedir. Knop, Hoecke ve Bosscher (2004) de yapmış oldukları çalışmada spor kültürü ve atmosfer farklılıklarının spor kurumlarını önemli kıldıklarını ve hükümetlerin spor politikalarının içeriklerinin kalitesini yükseltmek zorunda olduklarını ifade etmiştirler. Sam (2009) da Avustralya, Kanada, İngiltere ve Yeni Zellanda' da yapmış olduğu çalışmada spor organizasyonlarının idaresindeki başarısızlıkları vurgulamış ve bunun sebebini organizasyonların ticari hale getirilmiş olması olarak ifade etmiştir. Hükümet politikalarının 
bu yüzden elit spora yöneldiği ve alt yapıların gelişimlerinin engellenmiş olduğu ve hükümet politikalarının gözden geçirilme ihtiyacını doğurduğu sonucuna ulaşmıştır. Bayraktar (2003) de yaptığı çalışmada günümüzde, uluslararası yarışmalarda gelişmişliğin göstergesi, soğuk savaş aracı ve politik başarının ölçüsü olarak da çok amaçlı fonksiyonu olan spor, doğal olarak içinde bulunduğu toplumun sosyal yapısından etkilenmekte ve gelişme sürecini buna paralel olarak sürmekte olduğunu dile getirmiştir.

Çalışma sonucunda; yöneticilere daha fazla sayıda ulaşılıp nitel olan çalışma nicel ile desteklenmesi önerilebilir. Daha önce akademisyenler, milletvekilleri ve spor bölümü ile yapılmış bu çalışma spor alanından gelmeyen kişiler ile görüşülüp karşılaştırmalarda yapilabilir.

\section{Kaynakça}

Aykın, A. G. (2013). Meşrutiyetten Günümüze Türkiye'de Spor Politikaları Ve 1980 Sonrası $\quad$ Parti $\quad$ Ve Hükümet Programları İle Kalkınma Planlarında Sporun Yeri. Akademik Bakış Dergisi. 38 Eylül-Ekim Uluslararası Hakemli Sosyal Bilimler E-Dergisi. Issn:1694-528x.

Bayraktar, C. (2003). Sosyal Yapı Özelliklerinin Spora Etkisi. Uludağ Üniversitesi Eğitim Fakültesi Dergisi XVII(1). 19-36.

Costa, A. C. (2005). The Status And Future Of Sport Management: Delphi Study. Journal of Sport Management. 19(2). 117-142 https://doi.org/10.1123/jsm.19.2.117.

Doğu, G. (Editör: Mirzeoğlu, N.) (2011). Spor Bilimlerine Giriş. Spor Yayınevi ve Kitabevi. Ankara. 241271.

Ekmekçi ,R. (edt: Basım, N. ve Argan , M.)(2016). "Spor Yönetimi". Detay Yayıncılık, Ankara. s: 10-13.

Gökçe, Z. , Çam, İ. Ve Yazıcılar, İ. (2008). Spor Yöneticilerinin Liderlik Boyutlarının Araştırılması. Ege Bölgesi Örneği. Spor Yönetimi Ve Bilgi Teknolojileri Dergisi 3(1).

Güngörmüş, H.A., Yılmaz, B. \& Yenel, İ. F. (2004). Milletvekillerinin Türk Sporuna İlişkin Görüşleri, 8. Uluslararası Spor Bilimleri Kongresi. Kasım 17-20, Kemer / ANTALYA.

İnce, M. (2016). Spor ile Siyasetin İlişkisi Üzerine Bir Analiz; Sporu Siyasete Alet Etmek. Karabük Üniversitesi,Safranbolu Meslek Yüksekokulu, Karabük Sosyal Bilimler Enstitüsü Dergisi, 6(2).

Knop, P. D. , Hoecke, J. V and Bosscher, V. D. (2004). Quality Management in Sport Clubs. Management Review. 7(1). 57-77.

Masteralexis, L., Barr, C.A. and Hums, M.A. ( 2009). " Principles and Practice of Sport Management". Jones and Barlett Publishers : Boston, Toronto, London, Singapore. p: 26-29.

Miles, M. B., \& Huberman, A. M. (1994). Qualitative data analysis (2nd ed.). Thousand Oaks, CA: Sage Publications.

Özen, G., Koçak, F., Boran, F., Sunay, H. Ve Gedikli, N. (2012). Türk Spor Yönetimindeki Mevcut Sorunlara İlişkin Akademisyenlerin Görüşlerinin Değerlendirilmesi. Spormetre Beden Eğitimi Ve Spor Bilimleri Dergisi, X (4). 107-116.

Ramazanoğlu, F., Karahüseyinoğlu, M.F., Demirel, E. T., Ramazanoğlu, M.O., ve $\quad$ Altungül, O. (2005). Sporun Toplumsal Boyutlarının Değerlendirilmesi. Doğu Anadolu Bölgesi Araştırmaları Dergisi. 3(3). 153-157.

Saban, A., Ersoy, A. (2016). Ĕgitimde Nitel Araştırma Desenleri. Anı Yayıncılık. Ankara.

Sam, H. P. (2009). The Public Management of Sport. Journal Public Management Review. VI1(4). 499514. http://dxdoi.org/10.1080/14719030902989565.

Skinner, J. and Gilbert, K. (2007). Sport Management Education: Teaching and Learning for the Future: An Introduction to the Special Issue. Sport Management Review. 10(2). 125131. https://doi.org/10.1016/S1441-3523(07)70007-4

Sunay, H. (1998). "Spor Yöneticilerinin Nitelikleri Ve Eğitimi". Beden Eğitimi Spor Bilimleri Dergisi. III (1) : $59-68$.

Şahin, M.Y ve İmamoğlu, A. F. (2011). Akademisyenlerin ve Milletvekillerinin Spor Siyaset Etkileşimine Yönelik Görüşleri. Gazi Beden Eğitimi Ve Spor Bilimleri Dergisi Nisan , XVI(2). 25-44. 
Tobin GA, Begley CM (2004). Methodological rigour within a qualitative framework. J. Adv. Nurs. 48(4):388396.

Uyar, Y., Sunay, H. (2009). Üniversite Spor Yöneticiliği Eğitiminin Ankara İli Spor Kamuoyu Tarafindan Algılanma Düzeyleri Üzerine Bir Araştırma. Spormetre Beden Eğitimi Ve Spor Bilimleri Dergisi, VII (4). 141-149.

Victor , D. C. (2009). A Theory of Sport and Politics. The International Journal of the History of Sport 26(11): 1581-1610.

Vural, M. (2013). "Spor Genel Müdürlüğü Merkez Ve Taşra Teşkilatında Görev Yapan Spor Yöneticilerinin Düşünme Ve Karar Verme Stillerinin Incelenmesi ". Selçuk Üniversitesi Sağlık Bilimleri Enstitüsü Yüksek Lisans Tezi. Konya.

Yazıc1, A. G. (2014). Toplumsal Dinamizm Ve Spor. International Journal Of Turkish Literature Culture Education 3(1).394-405.

Yetim, A.A. (2000). Sporun Sosyal Görünümü. Gazi Beden Eğitimi ve Spor Bilimleri Dergisi (Gazi BESBD), $V(1) .61-72$

Yıldırım, A. ve Şimşek, H. (2013). Sosyal Bilimlerde Nitel Araştırma Yöntemleri (8. Baskl). Ankara: Seçkin Yayıncilik.

Zeigler, E. F. (2007). Sport Management Must Show Social Concern As İt Develops Tenable Theory. Journal Of Sport Management. 21(3). 297- 318. https://doi.org/10.1123/Jsm.213.297. 